\title{
Sensitivity analysis of the physical dynamics of the Fly River plume in Torres Strait
}

\author{
Yanfang Li ${ }^{\text {a, b, * }}$, Flavio Martins ${ }^{\mathrm{c}}$, Eric Wolanski ${ }^{\text {a, d }}$ \\ a TropWATER, James Cook University, Townsville, Queensland 4811, Australia \\ ${ }^{\mathrm{b}}$ Key Laboratory of Coastal Zone Environmental Processes and Ecological Remediation, Yantai Institute of Coastal Zone Research, Chinese Academy of \\ Sciences, Shandong, China \\ ${ }^{\mathrm{c}}$ CIMA Marine and Environmental Research Centre, University of Algarve, Portugal \\ d College of Marine and Environmental Sciences, James Cook University, Townsville, Queensland 4811, Australia
}

\section{A R T I C L E I N F O}

\section{Article history:}

Received 16 December 2016

Received in revised form

31 May 2017

Accepted 3 June 2017

Available online 5 June 2017

\section{Keywords:}

River plume

Altimetry

Modelling

Wind

Uncertainty

\begin{abstract}
A B S T R A C T
The intrusion in the Torres Strait of the Fly River plume polluted by mine tailings is an international water issue. To investigate the physical mechanisms involved in the intrusion process, numerical simulations were conducted to assess the relative influence of the bathymetry and the external forcing, namely the tides, the mean sea level slope across the strait, river runoff and wind forcing. The wind data from Horn Island, the only long-term wind station in the Torres Strait, is shown to be unreliable due to orographic effects. Mean sea level data from altimetry compare well with those from tide gauges in these shallow, reef-studded waters. The wind has a dominant effect on the mean sea level at seasonal and inter-annual periods. The resulting mean sea level difference across the strait fluctuated seasonally and strongly influenced the intrusion of the Fly River plume in the Torres Strait. The 3D finite-volume MOHID model reproduced the observation that the river plume starts by being stratified in the Gulf of Papua where it originates, and it mixes vertically when it enters the Torres Strait. The MOHID and the SLIM models were applied with different resolution to the Torres Strait and responded similarly to the external forcings. The predicted and observed Fly River plume intrusion in the eastern Torres Strait agreed well with each other, including the formation of patches due to flow reversals. However, the two models predicted a widely different Fly River plume in its far field in the western Torres Strait, the differences were attributed to the different bathymetry in the Australian and British-US bathymetry data for these poorly charted waters, which demonstrated the importance of the details of the bathymetry in controlling the extent of plume intrusion.
\end{abstract}

() 2017 Elsevier Ltd. All rights reserved.

\section{Introduction}

The Torres Strait (TS) is a shallow water body connecting the Gulf of Carpentaria (GoC) to the Coral Sea and the Gulf of Papua (GoP) via the continental shelf waters surrounding the Great Barrier Reef (GBR). The TS has a complex bathymetry with numerous shoals, islands, reefs and reef passages, especially on the continental shelf of the GBR. On the west of the strait, the waters are very shallow, reaching a maximum depth of only $20 \mathrm{~m}$. On the east side of the strait the GoP slopes uniformly to depths of about $100 \mathrm{~m}$ at the continental shelf break, while further offshore the Coral Sea

\footnotetext{
* Corresponding author. TropWATER, James Cook University, Townsville, Queensland 4811, Australia.

E-mail addresses: yanfang.li@jcu.edu.au, yfli@yic.ac.cn (Y. Li).
}

reaches depths $>4500 \mathrm{~m}$ (Fig. 1). The uniqueness of the GoP stems from its three large rivers, namely the Fly, Purari and Kikori Rivers, and two smaller rivers, namely the Aramia and Era Rivers that are next to the Fly and Purari Rivers. These five rivers essentially form a large river delta in the GoP. With rainfall in the highlands of Papua New Guinea (PNG) of 8-13 m annually, the combined freshwater discharge is substantial, about $15,000-20,000 \mathrm{~m}^{3} \mathrm{~s}^{-1}$ (Wolanski et al., 1984, 1990). This estimate of the freshwater discharge is only approximate because the PNG river discharges were measured a long way upstream from the river mouth. The freshwater discharge was found to be quasi-steady throughout the year with a minimal seasonal and inter-annual fluctuation. The individual river plumes merge to form a plume that covers most of the GoP, the plume being less than $20 \mathrm{~m}$ deep, progressively thinning with increasing distance from the coast (Apte \& Day, 1998; Harris, 1988; 


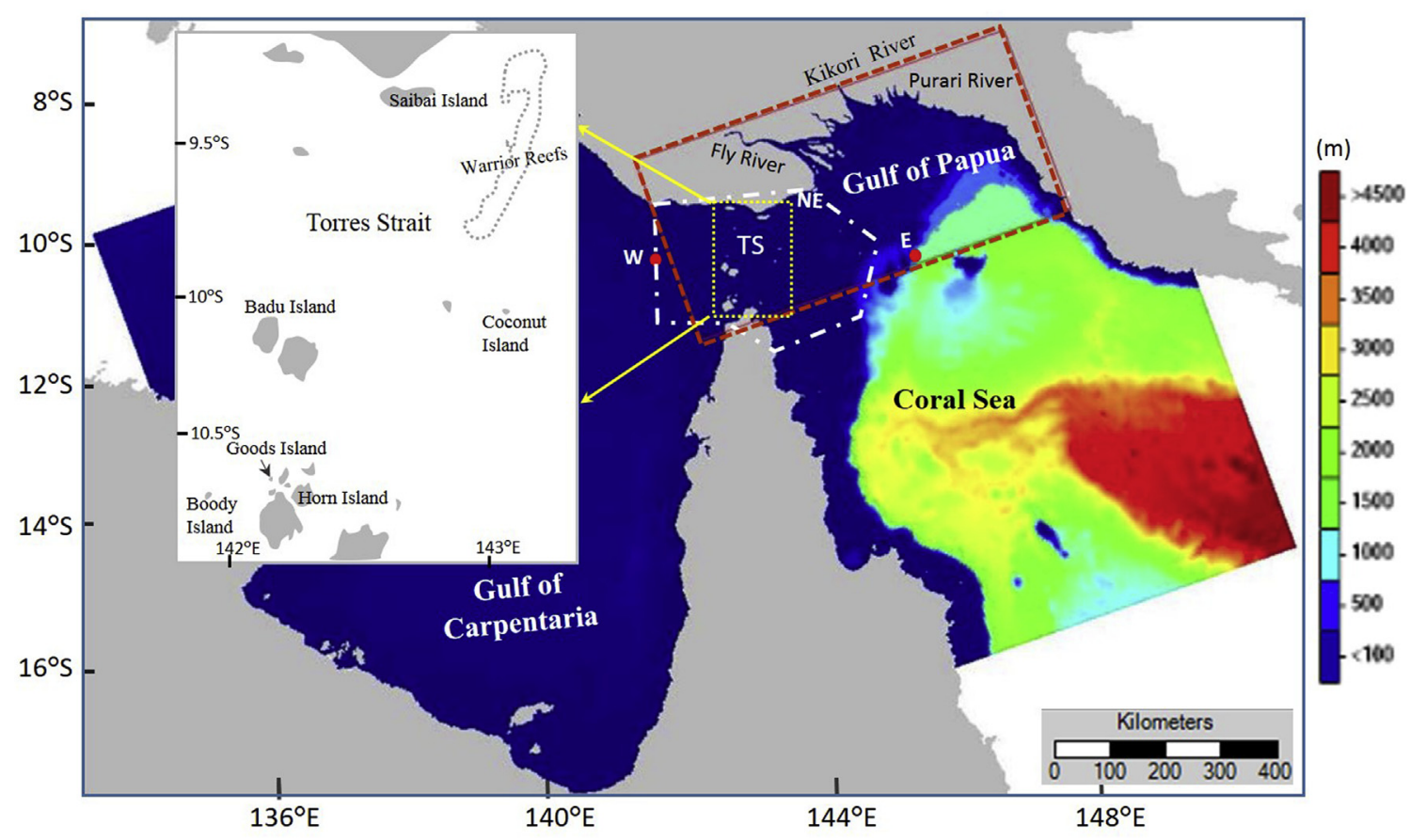

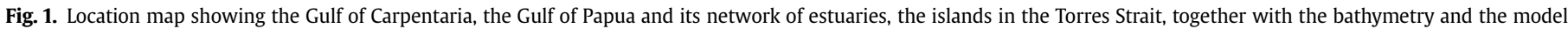

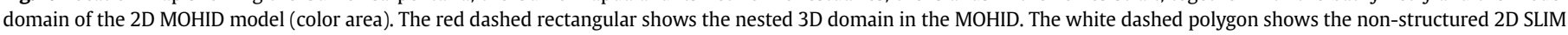

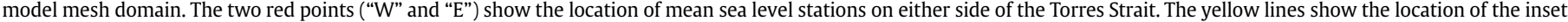

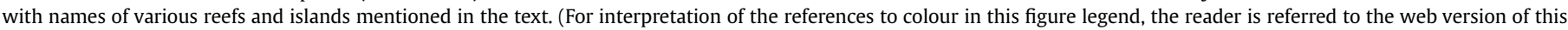
article.)

Harris et al., 1993; Wolanski et al., 1984, 1995; Walsh and Nittrouer, 2003). The Fly River in PNG is polluted by mine tailings (Bolton, 2009) and there is a concern that some of the pollutants may reach the Australian waters of the TS. To address this concern, several oceanographic studies of the salinity plume in TS were carried out in the 80's and 90's, though none since. Wolanski et al. (1984) found evidences of this plume intrusion in TS. A strong plume intrusion event in the northeastern TS was observed in 1994 with a large area of salinity less than 27 , with evidence for patchiness (Wolanski et al., 1999). This plume was observed to be always vertically well-mixed (Wolanski et al., 1993, 1995; 1999; Wolanski and Thompson, 1984).

The dynamics of river plumes over continental shelves are a well-studied phenomenon; in open systems, the dominant processes are the baroclinic effects, the wind and the prevailing oceanic circulation (e.g., MacDonald and Geyer, 2004; Nash and Moum, 2005; see a review in Delandmeter et al., 2015). In semiclosed systems, local oceanographic processes and wind shadows around islands and headlands generate patchiness (Delandmeter et al., 2015). The dynamics of the Fly River plume in TS are believed to be driven by the large oceanographic processes controlling the net circulation through the strait, as well as by local, small-scale oceanographic processes generated by the complex bathymetry with numerous shoals, reefs and islands. The largescale circulation through the shallow TS is driven by the mean sea level difference across the strait ( $\Delta \mathrm{MSL})$, the river runoff, the wind and large-scale oceanic forcings and it is presumably very sensitive to details of the bathymetry (Wolanski et al., 1984, 1995, 2013; Robertson et al., 1993; Ayukai and Wolanski, 1997; Li et al., 2015). There has never been a detailed assessment of the relative importance of these forcings that control the intrusion of the Fly River plume in TS.

In this paper we demonstrate that wind data from Horn Island, the only long-term wind station in the TS, are unreliable due to orographic effects. We also show that satellite altimetry-derived mean sea level (MSL) data are reliable even in these shallow, reef-studded waters. Additionally we show that the wind is the dominant, but not the only, forcing controlling the $\Delta$ MSL across the TS. We modeled the water circulation in the GoP and the TS using the 3-D finite-volume MOHID model; the model reproduced the observations that waters are salinity-stratified in the GoP and vertically well-mixed in the TS; the model also reproduces well the observations of the Fly River plume dilution and extent in the northeastern region of the TS. We also used the 2-D finite-element, high resolution SLIM model in the TS; the SLIM and MOHID predicted plume intrusion are similar in the northeastern region, with evidence of patchiness, but they differ markedly in the western region. This discrepancy is attributed to the two models using different bathymetry data in this region.

\section{Model and data}

\subsection{Bathymetry data}

There are three sources of bathymetry data. The British data were obtained from the General Bathymetric Chart of the Oceans (GEBCO), which is provided by the British Oceanographic Data Centre (BODC) with a 30 arc-second (approximately $926 \mathrm{~m}$ ) grid. The US Navy bathymetry data (DBDB2) were the same but also incorporated the 2002 eReef data that did not include numerous reefs and islands in the northern TS. This data resolves relatively coarsely the bathymetry around the islands and reefs of the TS (Fig. 2a).

The Australian data were obtained from the 2010 eReef data (http://www.deepreef.org/projects/48-depth-model-gbr.html), which was initially based on the 2010 GeoScience Australia data set, 


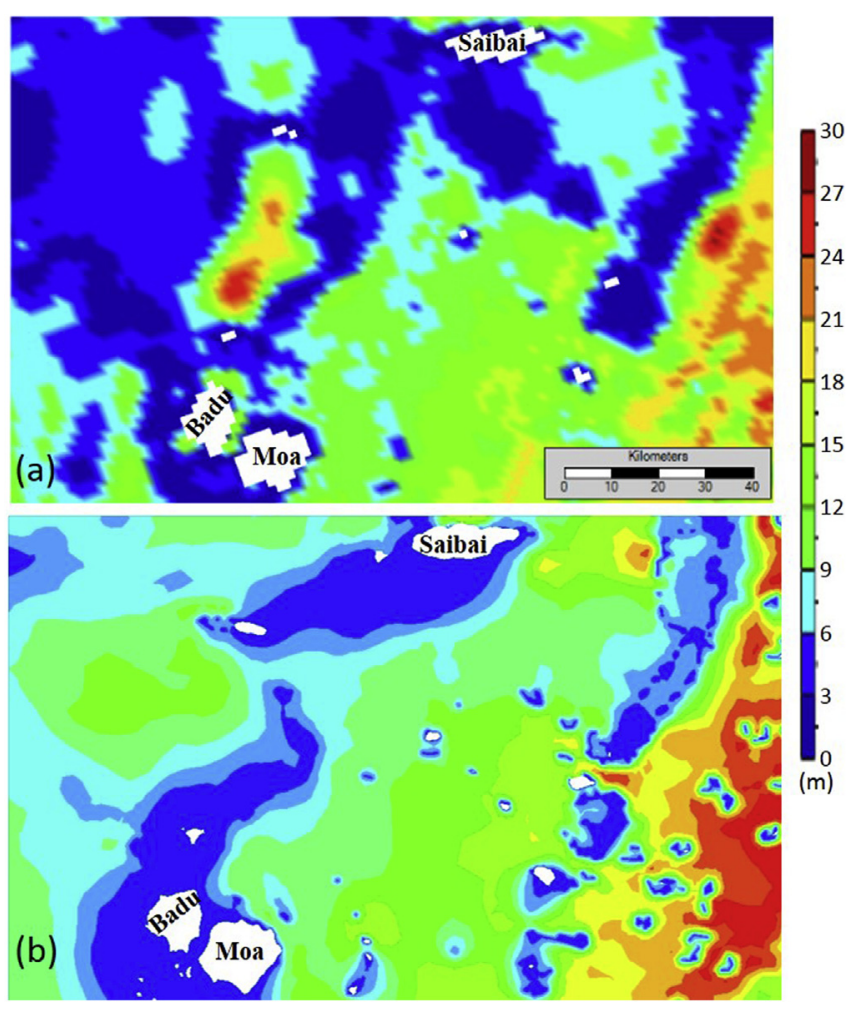

Fig. 2. The bathymetry (depth in $\mathrm{m}$ ) in the western Torres Strait (a) from GEBCO_08 data used in the MOHID model, and (b) provided by Australia eReef data used in the SLIM model.

to which we added the missing islands and reefs from the digitized global Australian map of islands and reefs (Fig. 2b).

\subsection{Altimetry, MODIS, wind, tide and river plume data}

The altimetry-derived MSL data being used in this study was produced by Ssalto /Duacs and distributed by Aviso, with support from Cnes (http://www.aviso.altimetry.fr/duacs). The gridded multi-mission altimetry products is available since 1993 with a horizontal grid resolution of $0.25^{\circ}$ and weekly interval. The various corrections (ionosphere delay, inverted barometer correction, solid earth and ocean tides etc.) have been applied to the altimeter measurements (Hernandez and Schaeffer, 2000). The weekly altimetry data were averaged to produce monthly mean data.

All the MODIS satellite views of the TS and described in Petus (2013) were reviewed. The area is extremely cloudy and only one cloud-free MODIS view of the GoP was found. We could not use MODIS views in TS itself to determine the extent of the turbid Fly River plume because the turbidity that the satellite sees is due to both advection of turbid Fly River plume waters as well as local resuspension; this is not the case in the GoP where the waters are much deeper and locally resuspended mud does not reach the surface (Ayukai and Wolanski, 1997).

The 3-hourly wind data at Horn island (frequently but incorrectly referred to in the literature as Thursday Island) and Coconut Island (a flat island only a few meters above sea level and located $\sim 130 \mathrm{~km}$ north-east of Horn Island; Fig. 1) were obtained from the Bureau of Meteorology. The Horn Island data spanned $>40$ years; the Coconut Island data spanned from 2013 to mid-2016. The comparison of the wind at Horn and Coconut Islands (Fig. 3) shows that the wind velocity was similar at the two islands during the monsoon season (December-March); however, during the trade

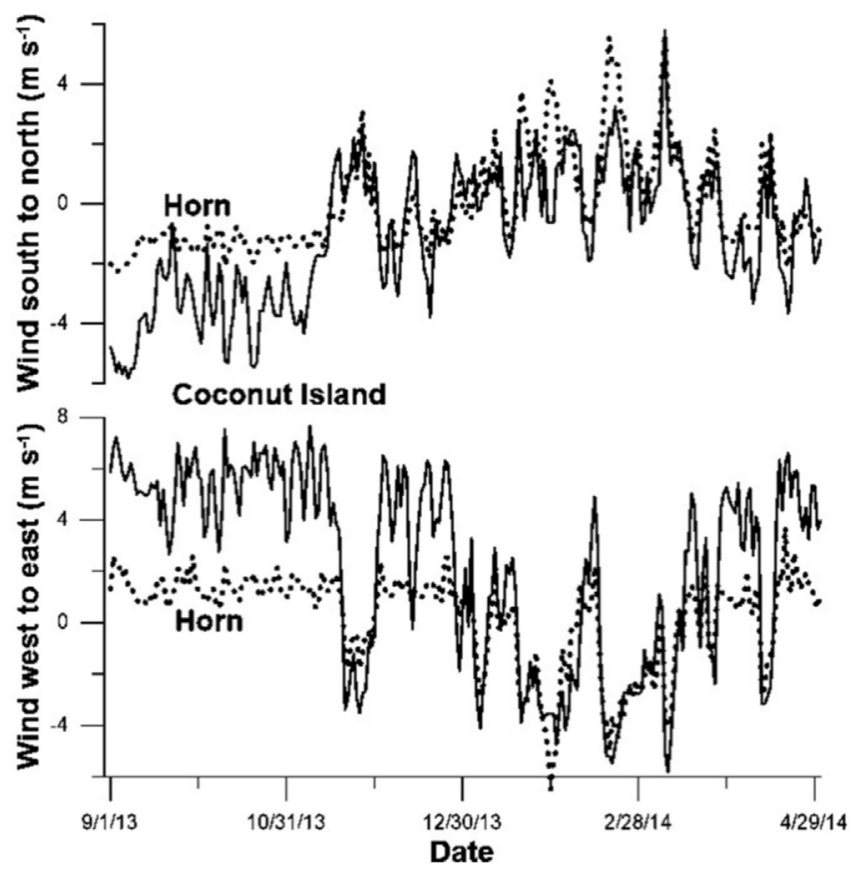

Fig. 3. Time-series plots of locally observed northward and eastward wind velocity near the airstrips at Horn and Coconut Islands for a period during 2013-2014.

wind season (May-October), the wind data at Coconut Island showed clearly the southeast trade wind while the data at Horn Island showed no such wind. This finding is due to orographic effects, namely that the Horn Island airport where the weather station is located is sheltered from the trade wind by the surrounding hills. Thus in this study we used only the Coconut Island wind data.

The monthly MSL data from tide gauges at Goods and Booby Islands were obtained from the Permanent Service for Mean Sea Level (PSMSL). The discharge of river plume data of Wolanski et al. (1984, 1988, 1995, and 1999) were used.

\subsection{MOHID model}

MOHID (www.mohid.com) is a free-surface, finite volume hydrostatic model (Martins et al., 2001). The model comprised a large external domain (Fig. 1) covering the GoC, the TS, the GoP, and the northern Coral Sea. It used a 2D-depth integrated configuration to solely propagate the tide into the boundary of the nested domain (Fig. 1, red rectangle) with a horizontal resolution of $\sim 4 \mathrm{~km}$. The model was forced at the open boundaries by the tides and MSL. The tides were synthesized from 14 tidal constituents, extracted from the FES2004 tidal data product (Lyard et al., 2006). MSL data were obtained from satellite altimetry. The fine grid nested domain covered the GoP and the TS with a horizontal resolution of $\sim 1.6 \mathrm{~km}$. The vertical layers comprised two parts: a top sigma domain located over a bottom Cartesian domain. The division between domains was located at $50 \mathrm{~m}$ depth, which coincides with the usual location for the top of the thermocline (Wolanski et al., 1995). Table 1 summarizes the vertical layers. The use of a Sigma domain on the top and a Cartesian domain at the bottom assured a high degree of horizontality to the layers, minimizing baroclinic interpolation errors (Winther and Evensen, 2006). The nested model was forced at the open boundaries by river discharge and wind. The freshwater discharges in the main rivers were assumed to stay constant through time (Wolanski et al., 1993). Table 2 summarizes the river discharges considered in the model. The British bathymetry data were used. 
Table 1

Vertical structure of the nested domain of the MOHID model.

\begin{tabular}{|c|c|c|c|c|}
\hline Domain & Layer & Layer thickness (\%) & Layer thickness (m) ${ }^{\mathrm{a}}$ & Layer base depth $(\mathrm{m})^{\mathrm{a}}$ \\
\hline \multirow[t]{11}{*}{ sigma } & 20 & 1.5 & 0.78 & -1.22 \\
\hline & 19 & 2.0 & 1.04 & -0.18 \\
\hline & 18 & 3.0 & 1.56 & 1.38 \\
\hline & 17 & 5.0 & 2.6 & 3.98 \\
\hline & 16 & 5.0 & 2.6 & 6.58 \\
\hline & 15 & 7.5 & 3.9 & 10.48 \\
\hline & 14 & 7.5 & 3.9 & 14.38 \\
\hline & 13 & 10.0 & 5.2 & 19.58 \\
\hline & 12 & 10.0 & 5.2 & 24.78 \\
\hline & 11 & 20.0 & 10.4 & 35.18 \\
\hline & 10 & 28.5 & 14.82 & 50 \\
\hline \multirow[t]{9}{*}{ Cartesian } & 9 & & 20 & 70 \\
\hline & 8 & & 30 & 100 \\
\hline & 7 & & 50 & 150 \\
\hline & 6 & & 100 & 250 \\
\hline & 5 & & 150 & 400 \\
\hline & 4 & & 200 & 600 \\
\hline & 3 & & 250 & 850 \\
\hline & 2 & & 500 & 1350 \\
\hline & 1 & & 650 & 2000 \\
\hline
\end{tabular}

${ }^{\text {a }}$ Relative to the $50 \mathrm{~m}$ base for the case of the sigma domain.

\subsection{SLIM model}

The second-generation Louvain-la-Neuve Ice-ocean Model (SLIM) is a 2D vertical integrated model and it has already been successfully used to model the circulation in the Great Barrier Reef and Torres Strait (Andutta et al., 2011, 2012, 2013; Lambrechts et al., 2008; Legrand et al., 2006; Wolanski et al., 2013). SLIM is a freesurface, hydrostatic, depth-averaged, primitive equation ocean model and it uses an unstructured mesh. The SLIM model domain was nested in the MOHID model domain (see the white dot-dashed polygon in Fig. 1) and the model was used to refine the predictions of the river plume intrusion in TS. The non-structured mesh of SLIM model allows for a high spatial resolution of $150 \mathrm{~m}$ near the coast, islands and reefs and lower resolution (up to $10 \mathrm{~km}$ ) in deeper water far from reefs (Fig. 2b). The Australian bathymetric data were used. The model was forced by the wind, the tides, and the altimetry-derived $\triangle \mathrm{MSL}$ across the TS (for details about the model set-up, see Wolanski et al. (2013)). A Eulerian advection-dispersion model was used to predict the freshwater plume intrusion; for that, the tidally-averaged salinity distribution predicted by the MOHID model was imposed along the eastern open boundary (line E-NE in Fig. 1).

\section{Results}

The Australian bathymetric data have a much higher resolution, and there is a significant difference in the bathymetry between the UK-US data and the Australian data to the North of Badu Island (Fig. 2).

Fig. 4 showed that the MSL data derived from altimetry compared favorably with those derived from tide gauges at Booby

Table 2

River freshwater discharges considered in the MOHID model.

\begin{tabular}{ll}
\hline River & Discharge $\left(\mathrm{m}^{3} \mathrm{~s}^{-1}\right)$ \\
\hline Fly & 6000 \\
Kikori & 4000 \\
Purari & 4000 \\
Aramia & 2000 \\
Era & 2000 \\
\hline
\end{tabular}

and Goods Islands (the locations are shown in Fig. 1). Occasional discrepancies occurred and these are expected near reefs and islands due to the complex flows around islands and the resulting large sea level slopes (Wolanski and Elliott, 2015). The comparison indicates that the satellite altimetry data are reliable and can be used to calculate $\triangle \mathrm{MSL}$ across the strait.

MSL fluctuations reflect the local dynamics particularly in shallow areas such as the TS (Ayukai and Wolanski, 1997; Frankcombe et al., 2013). The MSL fluctuated seasonally on either side of the TS (Fig. 5a). These seasonal fluctuations appeared to be mainly wind-driven; they were the largest at the western side of TS
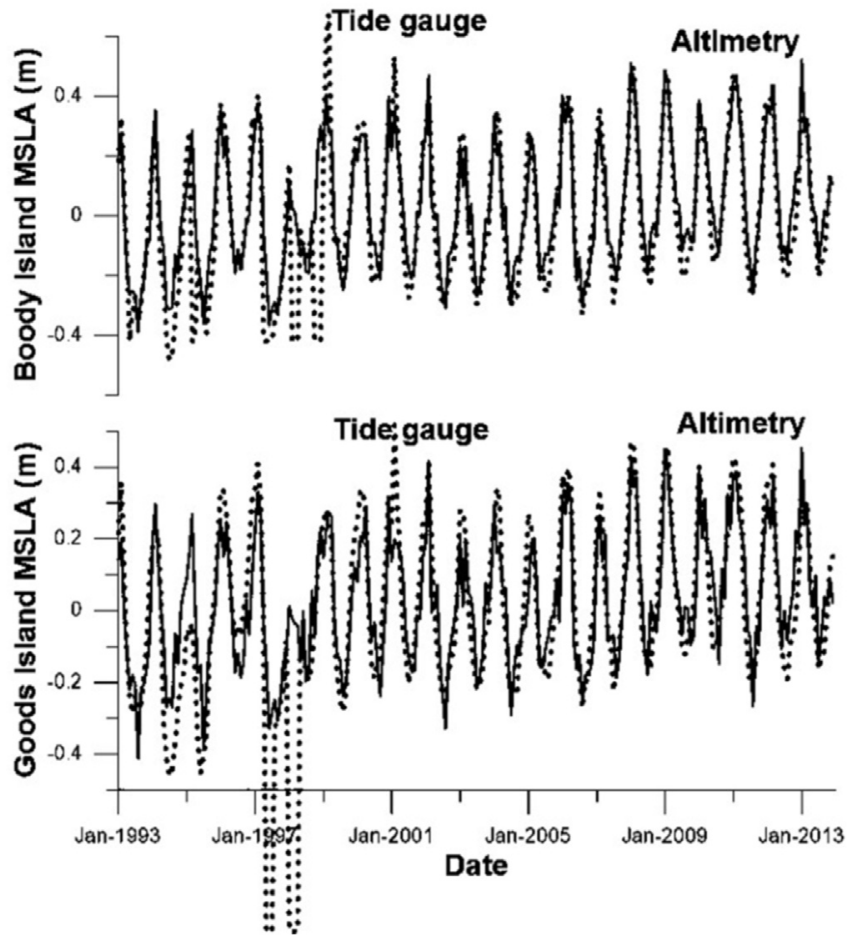

Fig. 4. Time-series plot of MSL anomaly measured from tide gauges and from satellite altimetry at Goods and Booby Islands in the southern Torres Strait (the location of the two gauges is shown in Fig. 1). 
facing the GoC where the MSL rose by $\sim 0.5 \mathrm{~m}$ in the monsoon season and decreased by $\sim 0.5 \mathrm{~m}$ in the trade wind season, i.e. the MSL fluctuated annually by $\sim 1 \mathrm{~m}$. During the trade wind season the MSL was higher on eastern side than on the western side of the TS, and the opposite prevailed during the monsoon season. Imbedded in these large seasonal MSL fluctuations, there were also smaller fluctuations (typically $\pm 0.1 \mathrm{~m}$ ) at shorter time scales, particularly so at the western side of the TS (Fig. 5b). The MSL fluctuations were relatively uniform across the western and eastern sides of the TS, respectively (not shown). As shown in Fig. 6 the $\Delta$ MSL across the TS fluctuated from $-0.4-0.6 \mathrm{~m}$ and it correlated strongly $\left(\mathrm{r}^{2}=0.65\right)$ with the wind component from $120^{\circ}$. This indicates that the wind was a dominant determinant of the $\Delta$ MSL across TS, although not the only determinant because some fluctuations of the $\Delta \mathrm{MSL}$ and the wind did not correlate with each other and these remain unexplained. The influence of the wind on $\Delta$ MSL across the TS was particularly dominant at seasonal time scales.

For the trade wind season, the MOHID model predicted a river plume that covered much of coastal waters in the GoP with a strong vertical stratification (Fig. 7b), while in the TS the model predicted vertically well-mixed conditions (Fig. 7c). This prediction matches well the field observations of Wolanski et al. (1984, 1990, 1993, 1995, and 1999). This finding is also supported by the theory of Simpson and Hunter (1974) following which the presence or absence of a vertical stratification depends on the value of $\log _{10} \mathrm{H} /$ $\mathrm{U}^{3}$, where $\mathrm{H}$ is the water depth, and $\mathrm{U}$ is the tidal current. In the GoP, $\mathrm{H} \sim 60 \mathrm{~m}$ and $\mathrm{U} \sim 0.1 \mathrm{~m} \mathrm{~s}^{-1}$ while in $\mathrm{TS}, \mathrm{H} \sim 20 \mathrm{~m}$ and $\mathrm{U}$ $\sim 0.6 \mathrm{~m} \mathrm{~s}^{-1}$ (Wolanski et al., 1995, 1999). Thus in the GoP a vertical stratification is expected because $\log _{10}\left(\mathrm{H} / \mathrm{U}^{3}\right) \sim 4.8$ while in TS $\log _{10}$ $\left(\mathrm{H} / \mathrm{U}^{3}\right)<2$ and the waters should indeed be vertically mixed well. Also in general agreement with the observations, the MOHID model predicted that the Fly River plume intruded in TS the most during the southeast trade wind season (Fig. 8f) when the $\Delta \mathrm{MSL}>0$ (i.e. the MSL was higher in the GoP than in the GoC), and that the plume intruded the least in TS during the monsoon season when $\Delta \mathrm{MSL}<0$ (Fig. 8d). During the southeast trade wind season the predicted plume width inside TS and its salinity depended on both the $\triangle \mathrm{MSL}$ and the wind (not shown). Most importantly, the MOHID predictions of the salinity within TS during the southeast trade wind season agreed well with the observations of September 1994

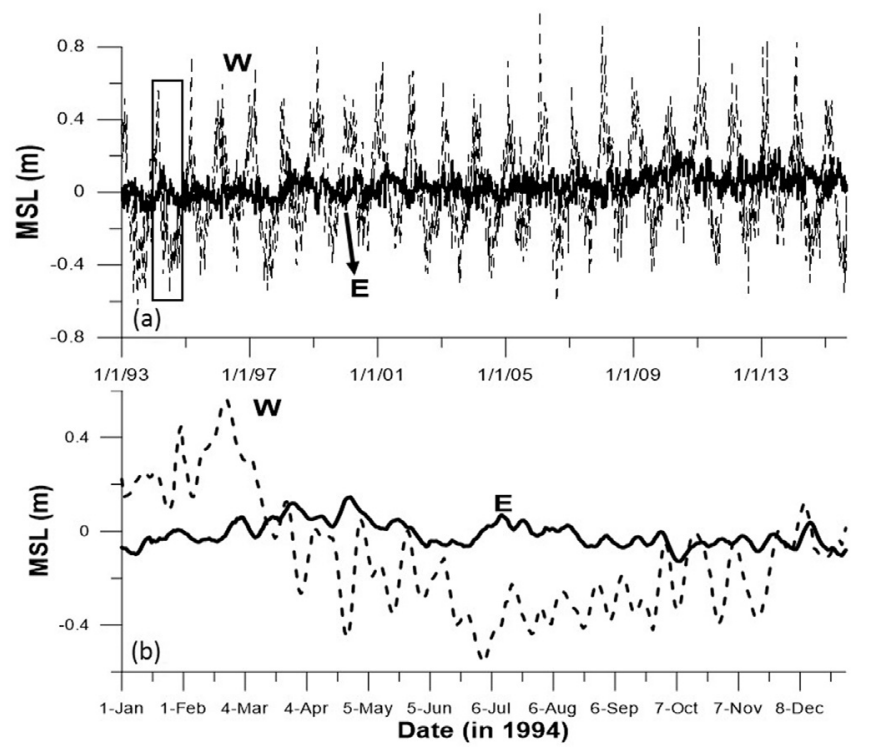

Fig. 5. Time-series plot of the MSL (in $\mathrm{m}$ ) on the western (W, dashed line) and eastern (E, solid line) sides of the Torres Strait (a) from 1993 to 2015 and (b) during 1994.

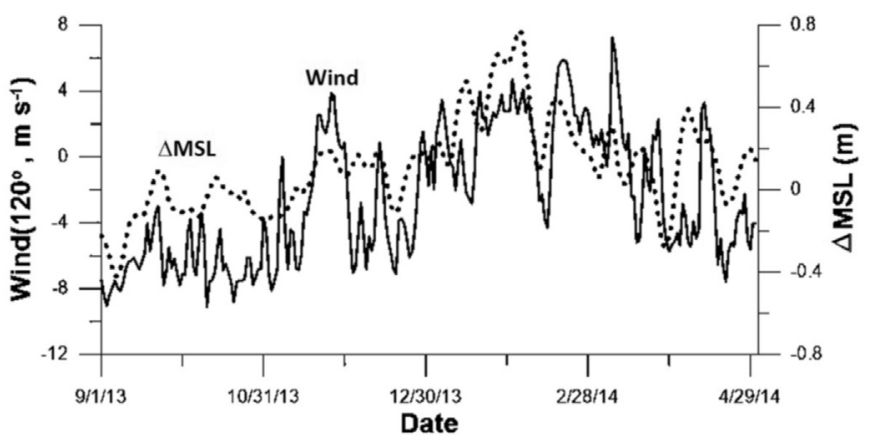

Fig. 6. Time-series plot of $\Delta \mathrm{MSL}$ (dashed line, in $\mathrm{m}$; from west to east) across the Torres Strait and the wind component velocity (solid line; in $\mathrm{m} \mathrm{s}^{-1}$; along $120^{\circ}$ at Coconut Island from September 2013 to May 2014.

(Fig. 8c). During the monsoon season (November-March), MOHID predicted a river plume that covered most of the GoP (Fig. 8d) and extended southeastward progressively thinning out with increasing distance from the coast. These predictions agreed well with the field observations of November 1979 (Fig. 8a). They also agreed qualitatively well with the true color image from MODIS (Fig. 8g) that shows the turbid waters of the Fly River plume extending straight offshore into the GoP). During the trade wind season the MOHID model predicted that the Fly River plume extended westward and southwestward to cross the whole width of the TS. During September 1994 there was a strong plume intrusion event (Fig. 8c) with surface salinity 20 in the Great North East Channel (Wolanski et al., 1999), the MOHID predictions (Fig. 8f) were also in general agreement with this observation. Following a transient wind event the fresh salinity tongue formed a low salinity patch around and east of Saibai Island in August 7-16,1994, and the MOHID model also predicted this patchiness (Fig. 8e). The MOHID model also predicted that in the trade wind season the plume was limited to the northern $1 / 3$ of the TS and extended across TS from east to west.

There are no Fly River plume intrusion data for the western region of the TS where the bathymetry is poorly known and where the British-US and the Australian bathymetry data differ markedly (Fig. 2). The fine resolution SLIM model was used to assess the likelihood of the Fly River plume reaching the western TS. Examples of the SLIM-predicted river plume intrusion in the TS are shown in Fig. 9a and b for various scenarios with different $\Delta$ MSL. It is apparent that the plume intrusion increases with increasing values of $\triangle$ MSL. The SLIM model predictions agree generally with those of the MOHID model in the eastern region of the TS (Fig. 9c and d). Thus the models suggest that during the trade wind season the Fly River plume intrusion in the northern $1 / 3$ of the eastern TS may be permanent, and the extent of this intrusion fluctuates with the wind and $\Delta$ MSL, with much lower salinity in the east than in the west. The model predictions differ however markedly in the western TS, where the SLIM model predicts that the river plume intrusion is blocked by the shallow waters between Badu and Saibai Islands (Fig. 2). The MOHID model does not predict such a blockage and the reason appears to be that it uses the British-US bathymetry, which shows deeper waters to the North of Badu Island.

\section{Discussion}

Although in the Torres Strait (TS) there had a large number of field oceanographic studies lasting weeks to 1 year in the late 1970's, 1980's and 1990's (Wolanski et al., 1984, 1990, 1993, 1995, 1999), there have been no oceanographic data in the last 20 years. All these available historical data were collected at different 


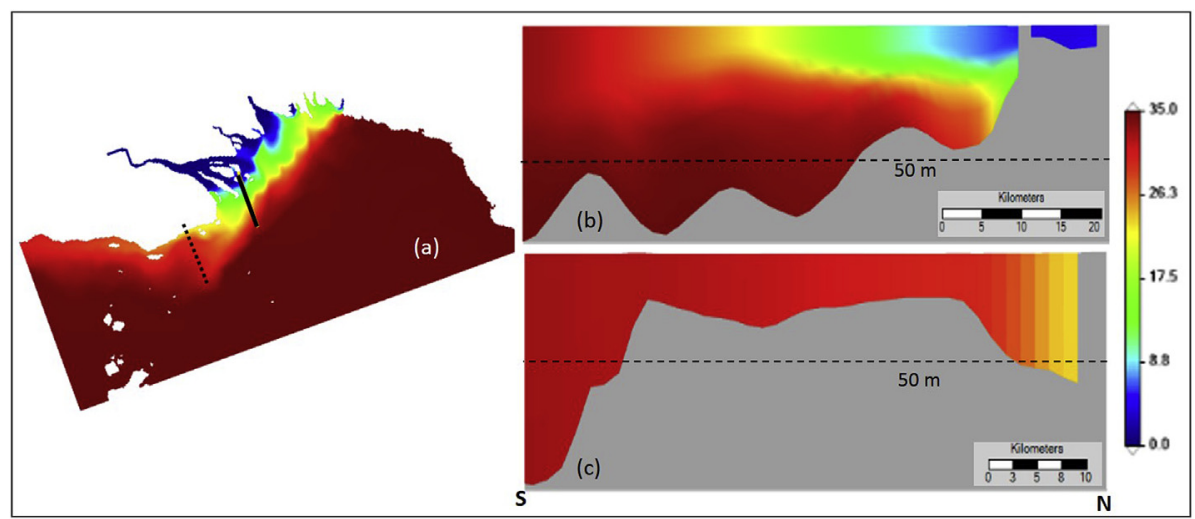

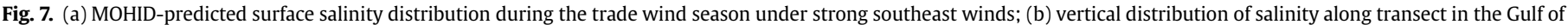
Papua shown by the black line in (a), and (c) salinity transect in the Torres Strait (black dashed line). The dashed line represents the isobath of $50 \mathrm{~m}$.
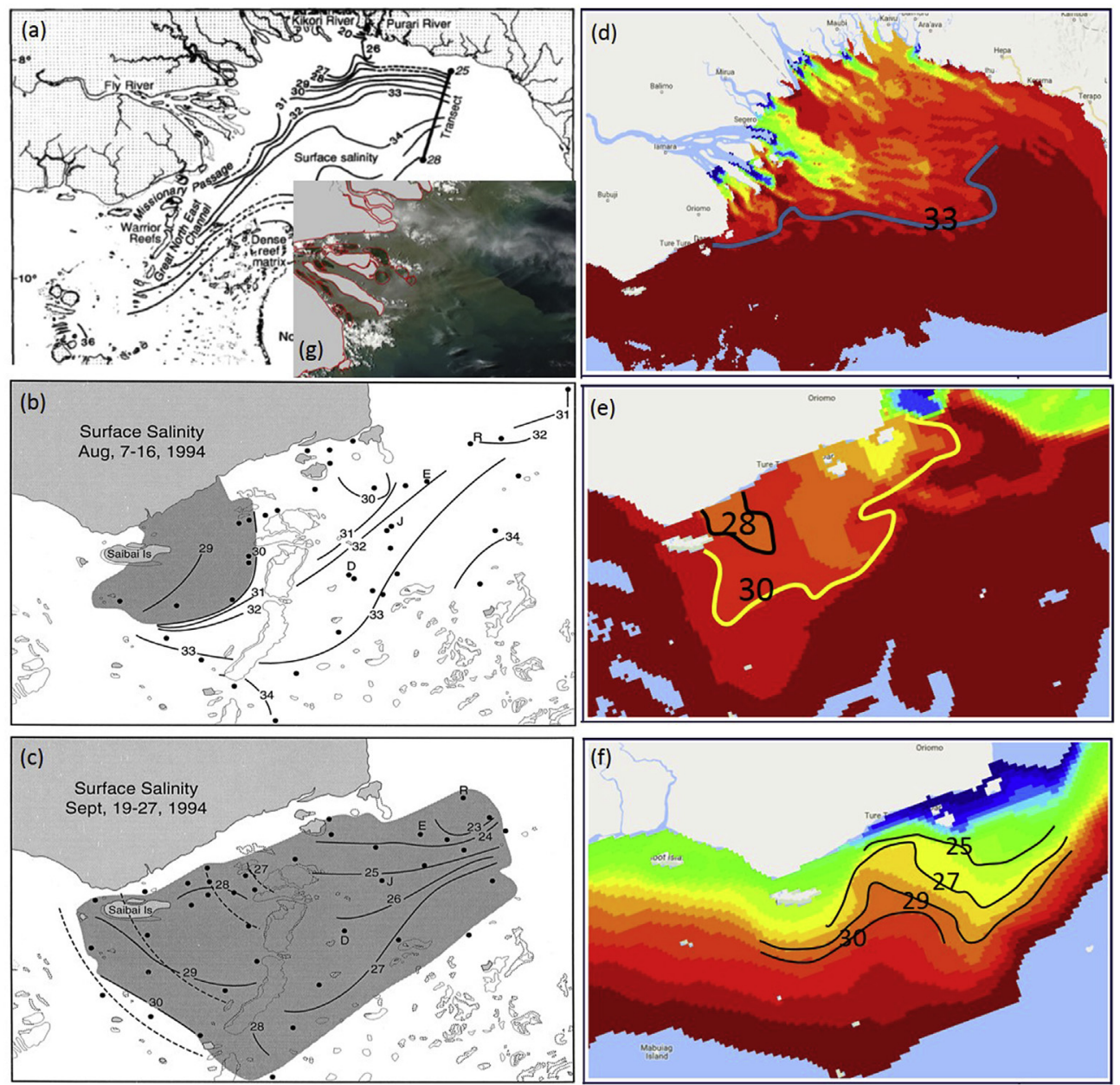

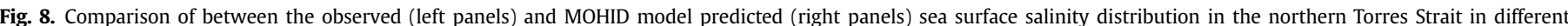

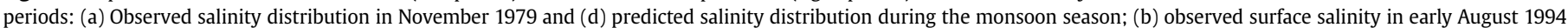

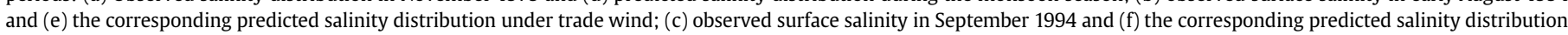

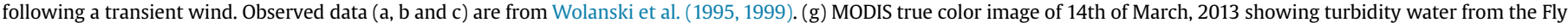
River plume. (a) is adapted from Wolanski et al. (1984). (b) and (c) are adapted from Wolanski et al. (1999).

times and in various regions of the TS; thus each data set in a given region needs to be analyzed separately to quantify the dominant processes and this knowledge from different regions must be brought together to quantify the dominant forces driving the intrusion of freshwater plume in TS. This was the method adopted by Wolanski et al. (2013) to produce their model of the net water circulation in TS. What is new in our study is that (1) during the trade wind season the Fly River plume intrusion in the northern $1 / 3$ of the eastern TS may be permanent, (2) the wind data at Horn Island, the only long-term wind station in TS, are degraded by 

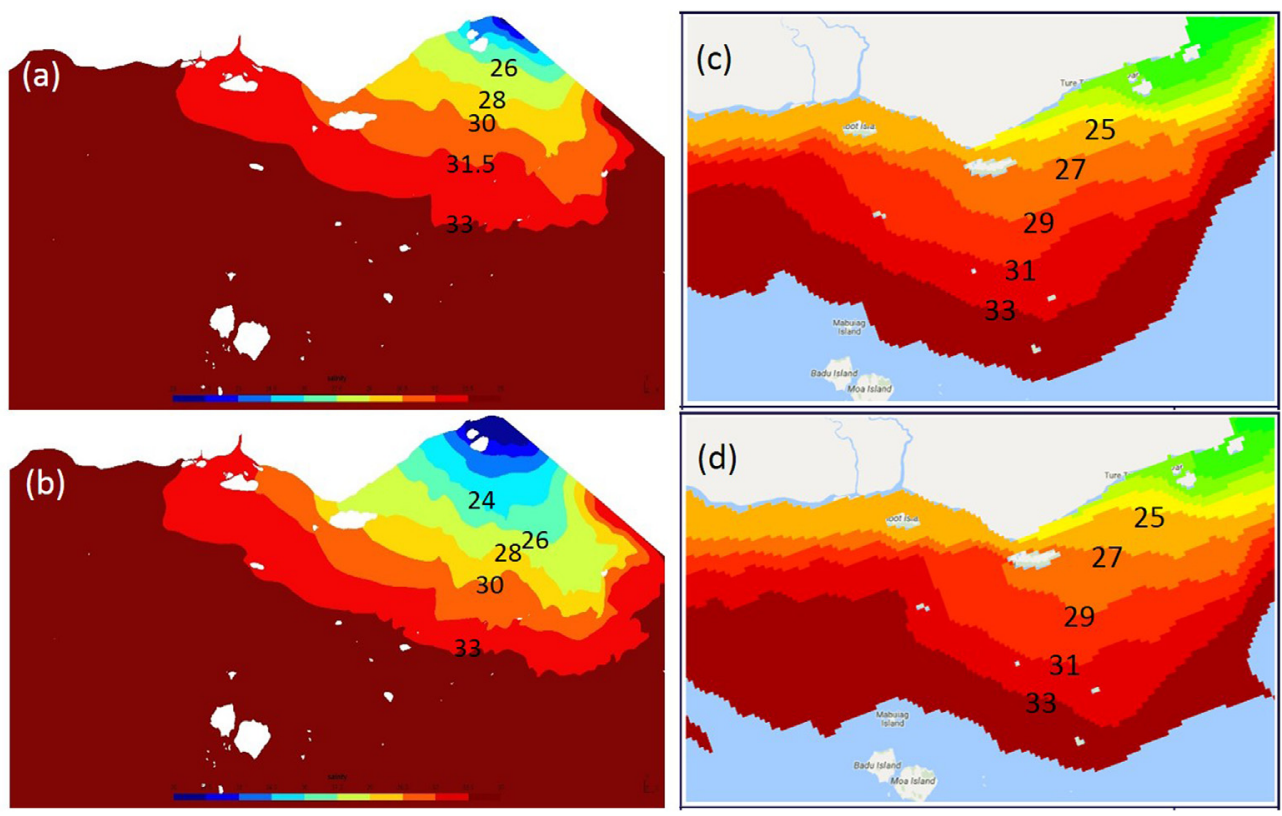

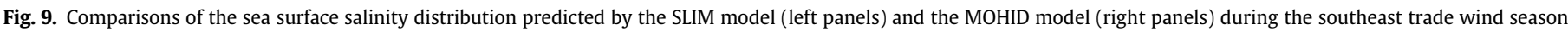

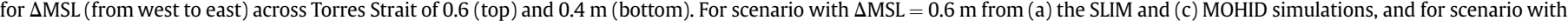
$\Delta \mathrm{MSL}=0.4 \mathrm{~m}$ from (b) the SLIM and (d) the MOHID models.

orographic effects; while the effect of topography on the wind is certainly not new to science, our finding is locally important because all previous oceanography studies of TS have used the degraded wind data from Horn Island. Thus we suggest that these studies may need to be re-visited; (3) the altimetry-derived MSL data in TS were verified against tide gauge data; (4) thus 20 years of altimetry data are available and they reveal a large, previously only known qualitatively but not quantitatively, seasonal and interannual variability of $\Delta$ MSL across the strait; (5) the $\Delta$ MSL across the TS is strongly but not uniquely related to the wind; (6) the wind fluctuations generate patchiness in the Fly River plume in the TS. Finally, the models suggest that the details of the largely unknown bathymetry in the northwestern TS may determine the westward extent of the Fly River plume intrusion in the TS; thus measuring this bathymetry is an important task to undertake in the future.

Finally, to quantify the processes controlling the intrusion of the Fly River plume in TS at different times of the year, a number of scenarios were carried out combining different wind season, $\Delta \mathrm{MSL}$ and tides. The altimetry sea level data were useful to explain field observations during the 1990s but could not help for the older field observations in the late 1970's and the 1980's when altimetry satellites were not yet operational. The only long-term wind data ( $>40$ years) in TS come from Horn Island and are unreliable due to orographic effects. Instead we used the wind data at Coconut Island, which spans only from 2013 onwards. Therefore it is only possible to use models to provide an average state of the freshwater intrusion, not a specific event in most cases using the different time data. However where other wind data exist then specific events can be modeled; such was the case for the Fly River plume study during the 1994 trade wind season, for which we found an encouraging agreement between the observed and model river plumes that included patches (Fig. 8). The model explained the observation of a strong salinity vertical stratification in the GoP and of vertically well-mixed waters in TS. It also explains the importance of the seasonal wind variation in driving the $\Delta$ MSL across TS, and that in turn this modulates the size and dilution of the Fly River plume intrusion in TS.

The details of the bathymetry appear to be important in these shallow waters. The British and the Australian bathymetry data are similar in the eastern region of the TS, where the MOHID and SLIM models predict a similar Fly River plume intrusion. However these two bathymetry data sets differ in the northwestern region of the TS, and as a result the two model predictions differ markedly in that region. There are however no river plume data to verify one model against the other in that region. The open boundaries in the eastern TS for the two models differ only in that the altimetry-derived $\Delta$ MSL is applied in the Coral Sea (Fig. 1) in the MOHID model and along the northeast boundary (line E-NE in Fig. 1) in the SLIM model. The open boundaries in the western TS for the two models are the same. Hence the different open boundaries for the two models are unlikely to explain the blocking of the Fly River plume in the western TS in one model and not in the other.

This study was limited to understanding the intrusion of the Fly River plume in TS and was undertaken in reply to community concern. There is still much uncertainty in assessing the frequency and extent of river plume intrusion in the western region. Neither it did address another potential, poorly understood, threat, namely the intrusion of Fly River fine sediment and its particle-bound contaminants. Salinity cannot be used as a proxy for the presence of Fly River sediment in TS, because of tidal resuspension. Further sediment dispersal studies suggested that only 3-11\% of the Fly River sediments were carried westwards across the strait (Heap et al., 2005; Hemer et al., 2004; Margvelashvili et al., 2008).

\section{Acknowledgements}

It is a pleasure to thank James Cook University, Jane Waterhouse, Jon Brodie, Jonathan Lambrechts, Tracey Wright, Susan Lesley and Gordon Bailey. The authors would like to thank Petus Caroline for providing the MODIS true color image. This study was supported by NESP Project 2.2.2 - Impacts of mine-derived pollution on Torres Strait environments and communities. 


\section{References}

Andutta, F.P., Ridd, P.V., Wolanski, E., 2011. Dynamics of hypersaline coastal waters in the Great barrier reef. Estuar. Coast. Shelf Sci. 94, 299-305.

Andutta, F., Kingsford, M., Wolanski, E., 2012. 'Sticky water' enables the retention of larvae in a reef mosaic. Estuar. Coast. Shelf Sci. 101, 54-63.

Andutta, F., Ridd, P.V., Wolanski, E., 2013. The age and the flushing time of the Great Barrier Reef waters. Cont. Shelf Res. 53, 11-19.

Apte, S.C., Day, G.M., 1998. Dissolved metal concentrations in the Torres Strait and Gulf of Papua. Mar. Pollut. Bull. 36 (4), 298-304.

Ayukai, T., Wolanski, E., 1997. Importance of biologically mediated removal of fine sediments from the Fly River plume, Papua New Guinea. Estuar. Coast. Shelf Sci. 44, 629-639.

Bolton, B.R., 2009. The Fly River, Papua New Guinea: Environmental Studies in an Impacted Tropical River System. Elsevier, Oxford, 656 pp.

Delandmeter, P., Lewis, S., Lambrechts, J., Deleersnijder, E., Legat, V., Wolanski, E., 2015. The transport and fate of riverine fine sediment exported to a semi-open system. Estuar. Coast. Shelf Sci. 167, 336-346.

Frankcombe, L.M., Spence, P., Hogg, A.M., England, M.H., 2013. Sea level changes forced by Southern Ocean winds. Geophys. Res. Lett. 40, 5710-5715.

Harris, P.T., 1988. Sediments, bedforms and bedload transport pathways on the continental shelf adjacent to Torres Strait, Australia-Papua New Guinea. Cont. Shelf Res. 8 (8), 979-1003.

Harris, P.T., Baker, E.K., Cole, A.R., Short, S.A., 1993. A preliminary study of sedimentation in the tidally dominated Fly River Delta, Gulf of Papua. Cont. Shel Res. 13 (4), 441-472.

Heap, A., Hemer, M., Daniell, J., Mathews, E., Harris, P., Kerwille, S., O'Grady, L., 2005. Biophysical processes in the Torre Strait Marine ecosystem - post cruise report. Geosci. Aust. 266, Record 2005/11, 112p.

Hemer, M., Harris, P., Coleman, R., Hunter, J., 2004. Sediment mobility due to currents and waves in the Torres Strait Gulf of Papua region. Cont. Shelf Res. 24, 2297-2316.

Hernandez, F., Schaeffer, P., 2000. Altimetric Mean Sea Surfaces and Gravity Anomaly Maps Inter-comparisons. Rapport n AVI-NT-011-5242-CLS, ed. CLS, Ramonville St Agne. pp. 48.

Lambrechts, J., Hanert, E., Deleersnijder, E., Bernard, P.E., Legat, V., Remacle, J.F., Wolanski, E., 2008. A multi-scale model of the hydrodynamics of the whole Great Barrier Reef. Estuar. Coast. Shelf Sci. 79, 143-151.

Legrand, S., Deleersnijder, E., Hanert, E., Legat, V., Wolanski, E., 2006. High-resolution unstructured meshes for hydrodynamics models of the Great Barrier Reef, Australia. Estuar. Coast. Shelf Sci. 68, 36-46.

Li, Y., Wolanski, E., Zhang, H., 2015. What processes control the net currents through shallow straits? A review with application to the Bohai Strait, China. Estuar. Coast. Shelf Sci. 158, 1-11.
Lyard, F., Lefèvre, F., Letellier, T., Francis, O., 2006. Modelling the global ocean tides: a modern insight from FES2004. Ocean. Dyn. 56, 394-415.

MacDonald, D.G., Geyer, W.R., 2004. Turbulent energy production and entrainment at a highly stratified estuarine front. J. Geophys. Res. Oceans 109, C05004.

Margvelashvili, N., Saint-Cast, F., Condie, S., 2008. Numerical modelling of the suspended sediment transport in Torres Strait. Cont. Shelf Res. 28 (16), 2241-2256.

Martins, F.A., Leitão, P.C., Silva, A., Neves, R., 2001. 3D modeling in the Sado estuary using a new generic vertical discretization approach. Oceanol. Acta 24, S51-S62.

Nash, J.D., Moum, J.N., 2005. River plumes as a source of large-amplitude internal waves in the coastal ocean. Nature 437, 400-403.

Petus, C., 2013. Application of MODIS Remote Sensing Imagery for Monitoring Turbid River Plumes from the Papua New Guinea in the Torres Strait Region: a Test Study. Report to the National Environmental Research Program. Reef and Rainforest Research Centre Limited, Cairns, 20 pp.

Robertson, A.I., Daniel, P.A., Dixon, P., Alongi, D.M., 1993. Pelagic biological processes along a salinity gradient in the Fly delta and adjacent river plume (Papua New Guinea). Cont. Shelf Res. 13, 205-224.

Simpson, J.H., Hunter, J.R., 1974. Fronts in the Irish sea. Nature 250, 404-406.

Walsh, J., Nittrouer, C., 2003. Contrasting styles of off-shelf sediment accumulation in New Guinea. Mar. Geol. 196, 105-125.

Winther, N., Evensen, G., 2006. A hybrid coordinate ocean model for shelf sea simulation. Ocean. Model. 13, 221-237.

Wolanski, E., Pickard, G., Jupp, D., 1984. river plumes, coral reefs and mixing in the Gulf of Papua and the northern Great Barrier Reef. Estuar. Coast. Shelf Sci. 18 291-314.

Wolanski, E., Thompson, R., 1984. Wind-driven circulation on the northern Great Barrier Reef continental shelf in summer. Estuar. Coast. Shelf Sci. 18, 271-289.

Wolanski, E., Ridd, P., Inoue M, ., 1988. Currents through Torres Strait. J. Phys. Oceanogr. 18, 1535-1545.

Wolanski, E., Trenorden, M., King, B., 1990. Fly River Estuary and Gulf of Papua: Oceanography and Sediment Dynamics. Data Report: November 1990. Report prepared for Ok Tedi Mining Ltd. Australian Institute of Marine Science.

Wolanski, E., King, B., Galloway, D., 1993. Fly River Estuary and Gulf of Papua. Prepared for Ok Tedi Mining. Australian Institute of Marine Science.

Wolanski, E., Norro, A., King, B., 1995. Water circulation in the Gulf of Papua. Cont Shelf Res. 15, 185-212.

Wolanski, E., Spagnol, S., King, B., Ayukai, T., 1999. Patchiness in the Fly River plume in Torres Strait. J. Mar. Syst. 18, 369-381.

Wolanski, E., Lambrechts, J., Thomas, C., Deleersnijder, E., 2013. The net water circulation through Torres Strait. Cont. Shelf Res. 64, 66-74.

Wolanski, E., Elliott, M., 2015. Estuarine Ecohydrology. An Introduction. Elsevier, Amsterdam, 322 pp. 